\title{
New taxa in Eucalyptus (Myrtaceae) from New South Wales and Queensland
}

\author{
K.D. Hill
}

\begin{abstract}
Hill, K.D. (National Herbarium of New South Wales, Royal Botanic Gardens, Mrs Macquaries Road, Sydney, NSW 2000, Australia) 1997. New taxa in Eucalyptus (Myrtaceae) from New South Wales and Queensland. Telopea 7(3): 187-198. Three new species of Eucalyptus (E. farinosa, E. subcaerulea and E. scopulorum) and one new subspecies (E. pachycalyx subsp. banyabba) from New South Wales and Queensland are described and illustrated. Distribution maps are provided, and conservation status is discussed. All taxa are regarded as rare or threatened.
\end{abstract}

\section{Introduction}

Three new species and one new subspecies of Eucalyptus from New South Wales and Queensland are described. All of the new species are classed as rare or threatened, and formal names are required in order to facilitate appropriate listing and action for conservation purposes.

1. Eucalyptus pachycalyx subsp. banyabba K.D. Hill, subsp. nov.

E. pachycalyci subsp. waajensi affinis sed foliis adultis juvenilibusque latioribus, foliis juvenilibus obtusatis differt.

Type: New South Wales: North Coast: Banyabba Nature Reserve, M.I.H. Brooker 12396 $\mathcal{E}$ A.V. Slee, 14 Oct 1995 (holo NSW; iso BRI, CANB, MEL).

Tree to $10 \mathrm{~m}$ tall, often several-stemmed. Bark smooth to base, shedding in scales, patchy light and dark grey, yellow and orange. Juvenile leaves grey-green, dull, opposite on early nodes, quickly becoming disjunct-opposite, ovate, apically rounded, 3-10 cm long, 2.2-5.5 cm wide; petioles to $2.3 \mathrm{~cm}$ long. Adult leaves grey-green, dull, disjunct-opposite, similifacial, broad-lanceolate, acute or apiculate, 5-13 cm long, $1.8-3.3 \mathrm{~cm}$ wide; petioles $1.2-2.3 \mathrm{~cm}$ long. Inflorescences axillary, frequently paired; umbellasters 7-flowered. Peduncles terete, 5-15 mm long. Pedicels terete, 1-3 mm long. Mature buds ovoid, 7-9 $\mathrm{mm}$ long, 5-6 mm diam. Outer calyptra shedding early. Inner persistent calyptra hemispherical, $1 / 2-2 / 3$ as long as hypanthium. Stamens irregularly flexed, all fertile. Anthers adnate, basifixed, ovoid, opening by longitudinal slits. Fruits cup-shaped, 3-4-locular, 6-7 mm long, 7-8 mm diam. Calyptra scar and stemonophore flat, $0.2-0.5 \mathrm{~mm}$ wide. Disc level, $1.5-2 \mathrm{~mm}$ wide, with regular radial cracking. Valves narrowly triangular, acuminate with style remnants, basally enclosed, vertically raised and apically exserted. (Fig. 1).

Notes: E. pachycalyx Maiden \& Blakely is a taxonomically isolated species most closely allied to E. squamosa Deane \& Maiden, these two taxa representing eastern outliers in the large and otherwise primarily Western Australian section Bisectaria (Pryor \& Johnson 1970). E. pachycalyx subsp. banyabba is readily distinguished from subspp. pachycalyx and waajensis by the lower length:breadth ratio in both adult and juvenile leaves, and the rounded juvenile leaves. Peduncles and pedicels tend also to be shorter (Table 1). The shared rounded buds and broad adult leaves suggest that subsp. banyabba 


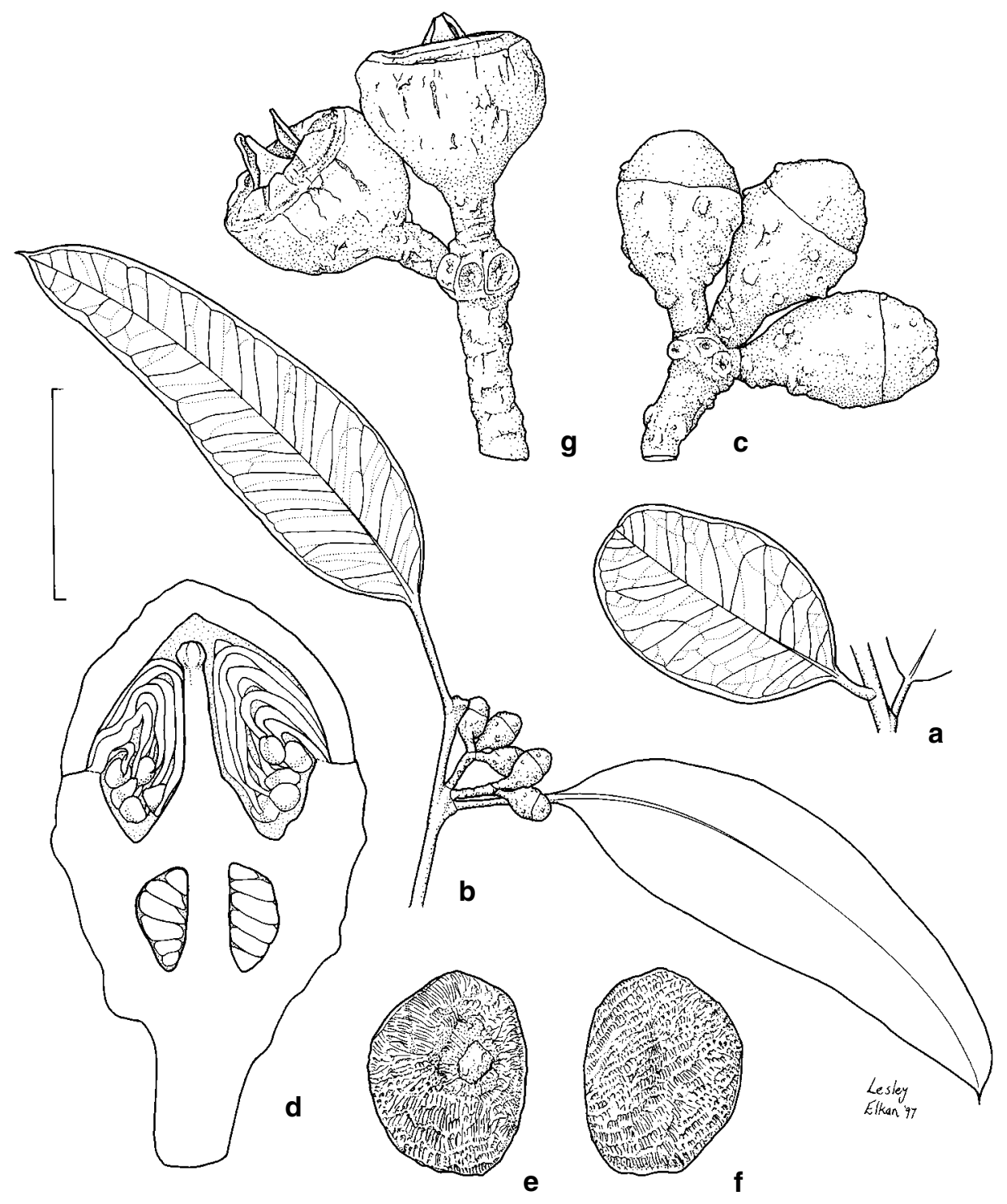

Fig. 1. E. pachycalyx subsp. banyabba. a, juvenile leaf. b, adult leaf and inflorescence. c, buds. d, transverse section of bud. e, f, seed. g, fruit. (a from Hill 4898 \& Richards, b-f from Thomas s.n.). Scale bar: $a, d=4 \mathrm{~cm}, b, c=1 \mathrm{~cm}, e=2 \mathrm{~mm}, \mathrm{f}=4 \mathrm{~mm}$. 
Table 1. Comparison of the subspecies of E. pachycalyx.

\begin{tabular}{|c|c|c|c|}
\hline Subspecies & pachycalyx & waajensis & banyabba \\
\hline \multirow[t]{2}{*}{ Juvenile leaves } & broad-lanceolate & broad-lanceolate & ovate \\
\hline & obtuse to rounded & acute & rounded \\
\hline $\mathrm{cm}$ & $6-15 \times 1.5-6$ & $5-16 \times 2.2-6$ & $3-10 \times 2.2-5.5$ \\
\hline Adult leaves & narrow-lanceolate & lanceolate & broad-lanceolate \\
\hline $\mathrm{cm}$ & $10-15 \times 1.3-2$ & $5-12 \times 1-2.2$ & $5-13 \times 1.8-3.3$ \\
\hline Petioles cm & $1.3-2$ & $1-2.5$ & $1.2-2.3$ \\
\hline Peduncles cm & $0.6-1.4$ & $1.2-1.6$ & $0.5-1.5$ \\
\hline Pedicels mm & $2-4$ & $4-5$ & $1-3$ \\
\hline Buds mm & $7-10 \times 4-5$ & $6-7 \times 4-5$ & $7-9 \times 5-6$ \\
\hline \multirow[t]{2}{*}{ Calyptra } & conical & rounded & rounded \\
\hline & $\begin{array}{l}\text { longer than } \\
\text { hypanthium }\end{array}$ & $\begin{array}{l}\text { as long as than } \\
\text { hypanthium }\end{array}$ & $\begin{array}{l}\text { shorter than } \\
\text { hypanthium }\end{array}$ \\
\hline Fruits $\mathrm{mm}$ & $5-6 \times 7-8$ & $5-6 \times 6-7$ & $6-7 \times 7-8$ \\
\hline
\end{tabular}

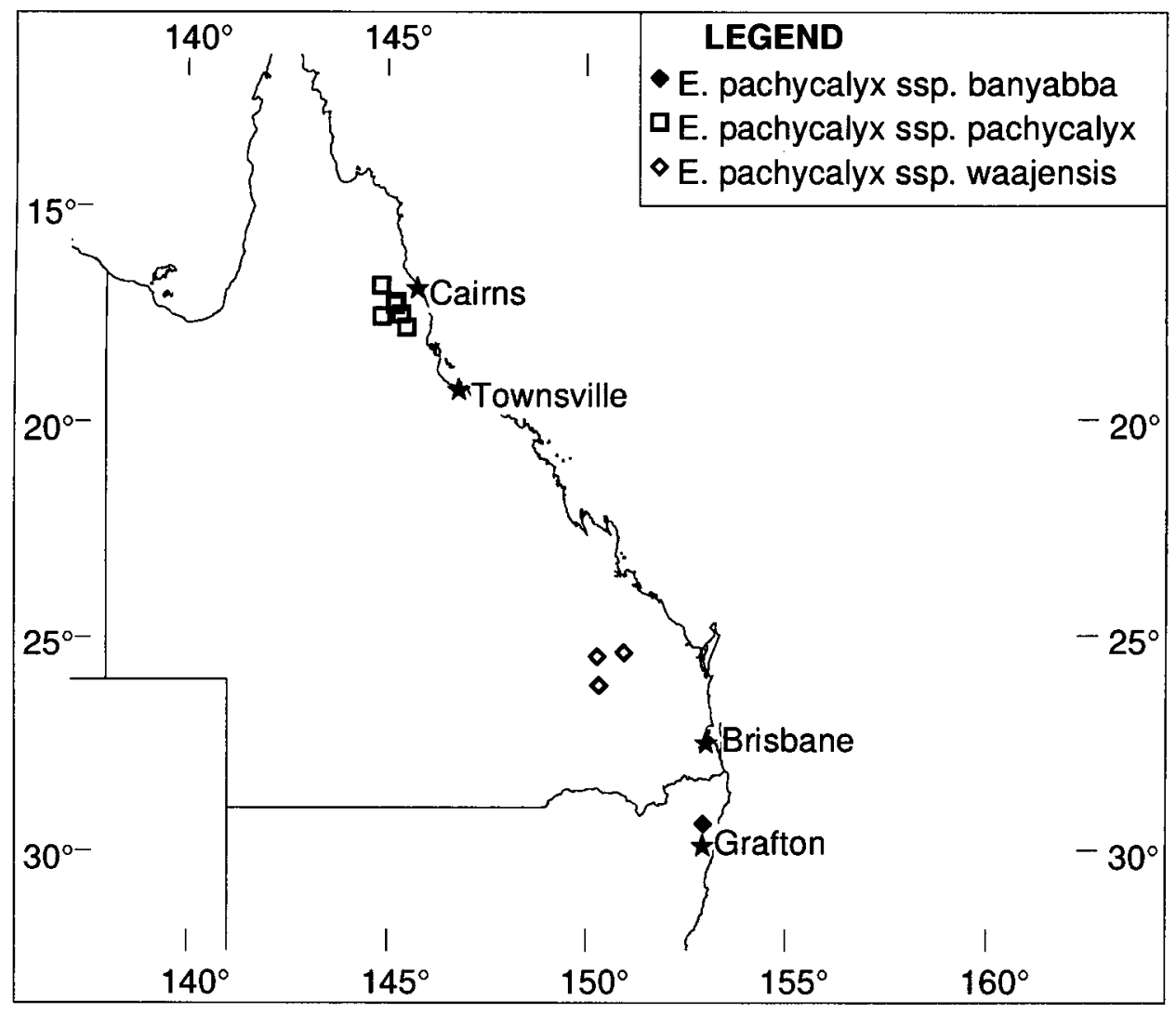

Fig. 2. Distribution of E. pachycalyx subspp. pachycalyx, waajensis and banyabba. 


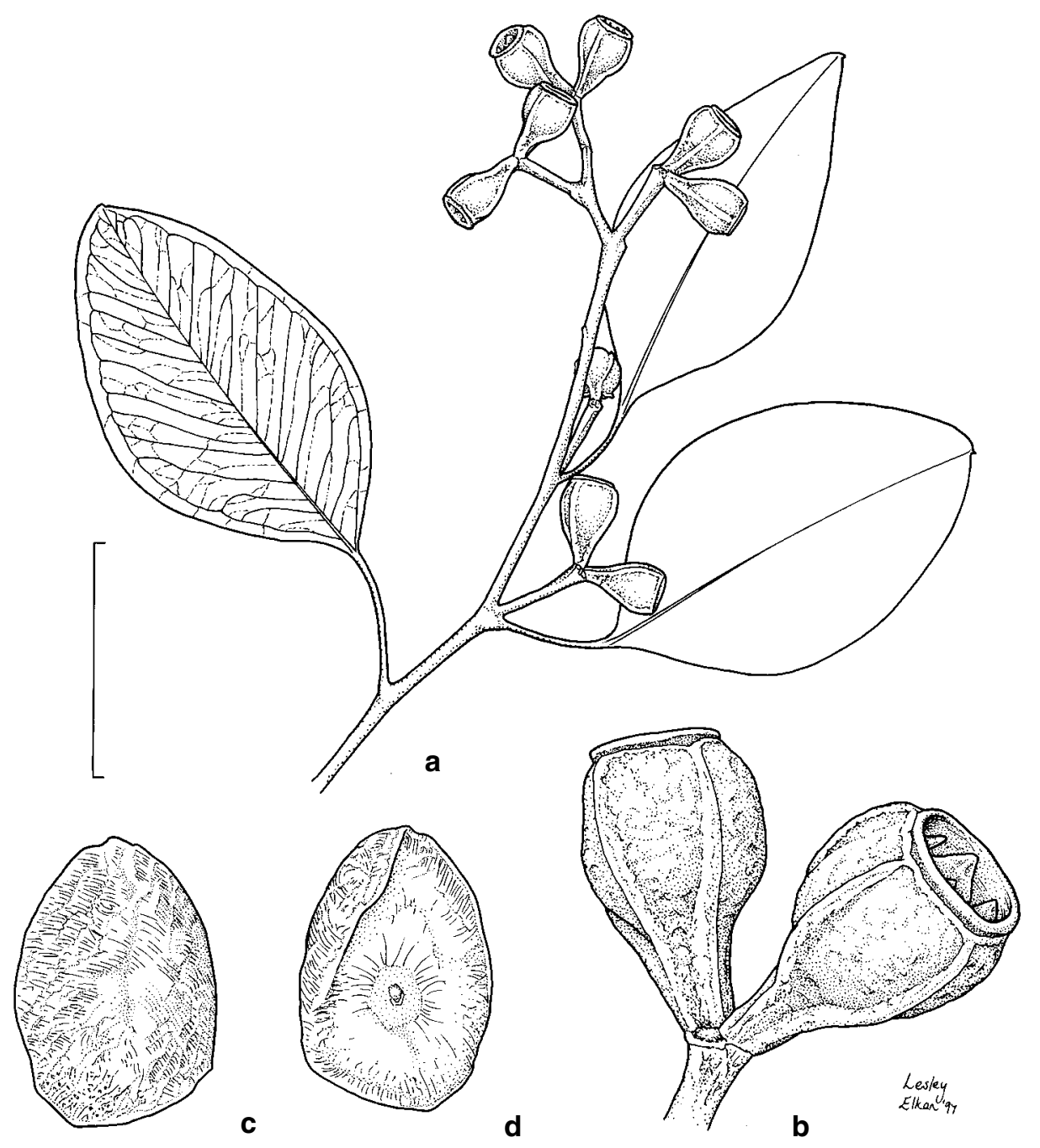

Fig. 3. E. farinosa. a, adult leaves, inflorescence and fruits. b, fruits. c, d, seed (from Hill 4823). Scale bar: $\mathrm{a}=4 \mathrm{~cm}, \mathrm{~b}=2 \mathrm{~mm}, \mathrm{c}=1 \mathrm{~cm}$. 
may be nearer to subsp. waajensis, although the rounded juvenile leaves shared with subsp. pachycalyx do not support this.

Distribution: known only from a few small stands in the Banyabba Nature Reserve in north-eastern New South Wales (Fig. 2).

Ecology: locally dominant in small patches on skeletal sandy soils over sandstone on slight rises. Individual plants are frequently many-stemmed as a result of successive regeneration from the lignotuber after fire, and the exact population sizes are consequently unclear, although likely to be alarmingly small.

Conservation status: $2 \mathrm{RC}$.

The epithet is taken from the occurrence of this subspecies in the Banyabba Nature Reserve.

Selected specimens (from 4 examined): New South Wales: North Coast: Banyabba Nature Reserve, Thomas s.n., 1994 (NSW 206468); Banyabba fire trail, Hill 4898 \& Richards, 29 Oct 1996 (NSW).

\section{Eucalyptus farinosa K.D. Hill, sp. nov.}

E. quadricostatae affinis sed ramulis, foliis fructibusque glaucis, foliis minoribus latioribusque differt.

Type: Queensland: track to top of Mt Stewart, W of Charters Towers, K.D. Hill 4823, 11 Oct 1996 (holo NSW; iso BRI, CANB).

Tree to $8 \mathrm{~m}$ tall. Bark hard dark grey ironbark throughout. Small branchlets strongly glaucous. Juvenile leaves not seen. Adult leaves grey-green with a white glaucous wax bloom, dull, disjunct-opposite, similifacial, ovate to orbicular, acute to rounded, 6-10 $\mathrm{cm}$ long, 3-6 cm wide; petioles 2.0-3.0 cm long. Inflorescences compound, often axillary; umbellasters 7-flowered. Peduncles terete or weakly angular, 7-15 mm long. Pedicels quadrangular, gradually expanded apically and merging into hypathium, 3-5 $\mathrm{mm}$ long. Mature buds not seen. Fruits strongly glaucous, quadrangular, cup-shaped, 4-5-locular, 9-12 mm long, 8-10 $\mathrm{mm}$ diam. Calyptra scar and stemonophore flat, c. $0.5 \mathrm{~mm}$ wide. Disc vertically depressed, $1-1.5 \mathrm{~mm}$ wide. Valves broadly triangular, acute, steeply raised, tips level to almost level with stemonophore or sometimes slightly exserted. (Fig. 3).

Notes: E. farinosa is nearest to E. quadricostata Brooker, from which it can be distinguished by the strongly glaucous twigs, leaves and fruits, the broader and more rounded leaves, and the shorter peduncles and pedicels (Table 2). Only a single collection of this species was examined (the type), although the population of over 1000 individuals across a range of more than $10 \mathrm{~km}$ was examined in the field.

Both E. farinosa and E quadricostata belong to Section Adnataria (Pryor \& Johnson 1970), a large and predominantly eastern Australian group that includes the boxes and ironbarks. Within that section, these two species are placed in a series defined by possession of hard ironbark, an outer calyptra that sheds early, anthers that dehisce through lateral slits, and absence of staminodes. This series includes the widespread species E. crebra and E. siderophloia. Pryor \& Johnson (op. cit.) had named this group Series Pruinosae on the (mistaken) assumption that E. pruinosa from northern Australia also belonged here. This was corrected by Brooker (1985), who suggested that a series name Crebrae would be appropriate. Chippendale (1988) used the series name Siderophloiae for the same group, revising the circumscription from that used by Blakely (1934), who first erected the name at series rank. Within the series, the two species discussed are readily distinguished by the quadrangular fruits.

Distribution: known only from Mt Stewart, west of Charters Towers (Fig. 4). 
Ecology: locally frequent but restricted to shallow gritty soils on the slopes of a steep granite range. This species is the dominant tree on steep dry slopes.

Conservation status: $2 \mathrm{R}-$.

The epithet is from the Latin farinosus, floury or mealy, in reference to the thick white coating on the leaves, buds and fruits.

3. Eucalyptus scopulorum K.D. Hill, sp. nov.

E. caleyi affinis sed foliis adultis juvenilibusque angustioribus, ramulis alabastrisque non glaucis differt.

Type: New South Wales: Northern Tablelands: Peregrine Point, Gibraltar Range State Forest (29³6'54"S 152¹2'04"E), K.D. Hill 4887 E P.G. Richards, 28 Oct 1996 (holo NSW; iso BRI, CANB, $\mathrm{K}, \mathrm{MEL})$.

Table 2. Comparison of E. quadricostata and E. farinosa.

\section{E. quadricostata $\quad$ E. farinosa}

Adult leaves

lanceolate

ovate to orbicular

$\mathrm{cm}$

$11-15 \times 1.5-2.2$

$6-10 \times 3-6$

Petioles cm

$1.3-2.7$

$2.0-3.0$

Peduncles mm

$12-20$

$7-15$

Pedicels $\mathrm{mm}$

5-7

$3-5$

Fruits $\mathrm{mm}$

$10-14 \times 8-10$

$9-12 \times 8-10$

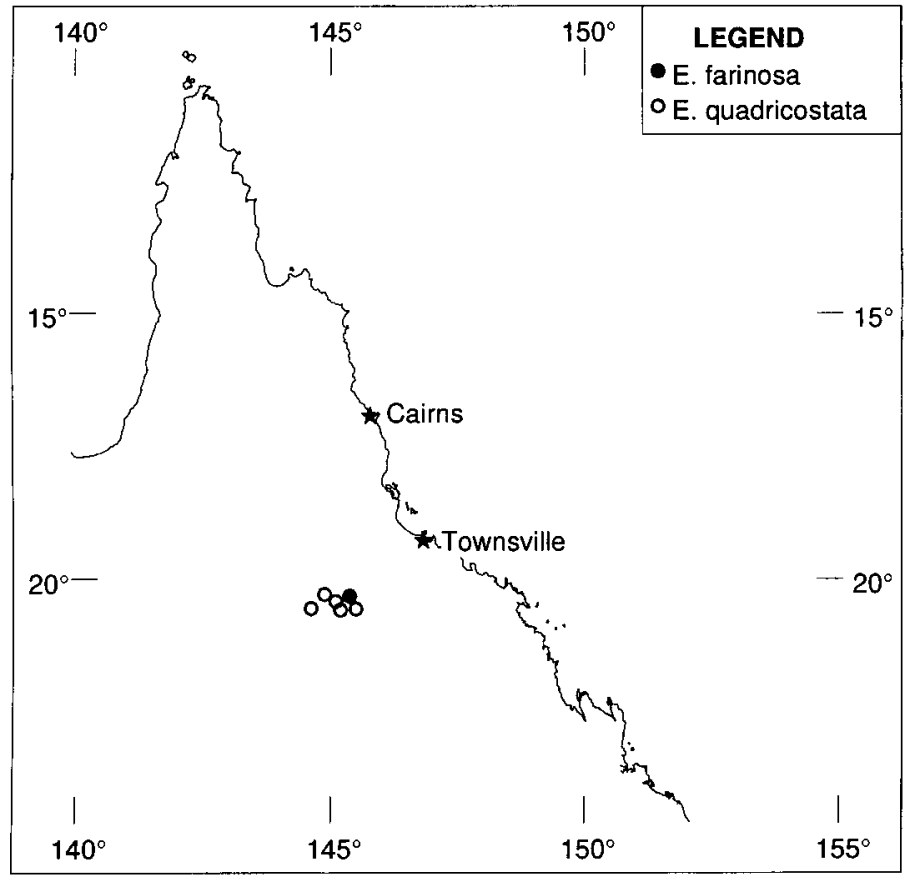

Fig. 4. Distribution of E. farinosa and E. quadricostata. 
Tree to $8 \mathrm{~m}$ tall. Bark pale grey corky ironbark throughout. Juvenile leaves grey-green, dull, disjunct-opposite, narrow-elliptical to elliptical, $3.5-9 \mathrm{~cm}$ long, $1.8-3.0 \mathrm{~cm}$ wide, apically rounded or obtuse; petioles $1-5 \mathrm{~mm}$ long. Adult leaves grey-green, dull, disjunct-opposite, similifacial, broad-lanceolate, acuminate, $6-11 \mathrm{~cm}$ long, $1.3-3.4 \mathrm{~cm}$ wide; petioles $0.8-2.5 \mathrm{~cm}$ long. Inflorescences simple or compound, terminal or axillary; umbellasters 7-flowered. Peduncles terete or weakly angular, $6-18 \mathrm{~mm}$ long. Pedicels terete or weakly angular, apically expanding and merging into hypanthium, $3-8 \mathrm{~mm}$ long. Mature buds fusiform, 7-9 $\mathrm{mm}$ long, $3.5-4.5 \mathrm{~mm}$ diam. Outer calyptra shed long before anthesis. Inner persistent calyptra conical, acute, about half as long as hypanthium, distinctly narrower than hypanthium. Stamens regularly inflexed, outer rows infertile. Anthers adnate, obliquely basifixed, cuboid, opening by terminal pores. Fruits obconical to barrel-shaped, 3-4-locular, 6-9 mm long, 5-7 mm diam. Calyptra scar and stemonophore flat, c. $0.5 \mathrm{~mm}$ wide. Disc vertically depressed, 1-1.5 $\mathrm{mm}$ wide. Valves broadly triangular, obtuse, steeply raised, deeply enclosed. (Fig. 5).

Notes: the corky ironbark, the early shedding outer calyptra, the anthers that open by terminal pores and the presence of staminodes place E. scopulorum in the E. paniculata Sm. group (series Paniculatae, Pryor \& Johnson 1970). The thick, broad, dull, similifacial adult and juvenile leaves and the rounded to obtuse juvenile leaves suggest that it is nearest to E. caleyi Maiden, from which it differs in the lower length:breadth ratio in both adult and juvenile leaves and the lack of any glaucousness. In particular, juvenile leaves of E. scopulorum range between about 0.3 and 0.5 in length: breadth ratio, whereas the range in E. caleyi is between 0.6 and 1.0. E. fusiformis Boland \& Kleinig could also be confused with E. scopulorum, but can be distinguished by the narrower and thinner adult and juvenile leaves, and the more slender fruits (Table 3).

Distribution: known only from a few small stands in the Gibraltar Range State Forest in the New England region of north-eastern New South Wales (Fig. 6).

Ecology: locally dominant but extremely restricted, occurring only in crevices on steep acid porphyry cliffs. E. notabilis Maiden and Brachychiton populneus (Schott \& Endl.) R.Br. occur in association.

Table 3. Comparison of E. caleyi, E. fusiformis and E. scopulorum.

\begin{tabular}{|c|c|c|c|}
\hline & E. caleyi & E. fusiformis & E. scopulorum \\
\hline Juvenile leaves & orbicular & lanceolate & $\begin{array}{l}\text { narrow-elliptical } \\
\text { to elliptical }\end{array}$ \\
\hline $\mathrm{cm}$ & $4-10 \times 3-7$ & $15-20 \times 2.5-3.2$ & $3.5-9 \times 1.8-3.0$ \\
\hline Adult leaves & $\begin{array}{l}\text { lanceolate to } \\
\text { broad-lanceolate }\end{array}$ & lanceolate & broad-lanceolate \\
\hline $\mathrm{cm}$ & $5-10 \times 1.5-4$ & $9-15 \times 1.1-2.5$ & $6-11 \times 1.3-3.4$ \\
\hline Petioles cm & $1.4-2.3$ & $1.2-2.0$ & $0.8-2.5$ \\
\hline Peduncles mm & $12-25$ & $3-20$ & $6-18$ \\
\hline Pedicels mm & $5-10$ & $2-6$ & $3-8$ \\
\hline Buds mm & $6-8 \times 4-5$ & $5-8 \times 3-4$ & $7-9 \times 3.5-4.5$ \\
\hline Fruits mm & $6-10 \times 5-8$ & $5-9 \times 4-5$ & $6-9 \times 5-7$ \\
\hline
\end{tabular}




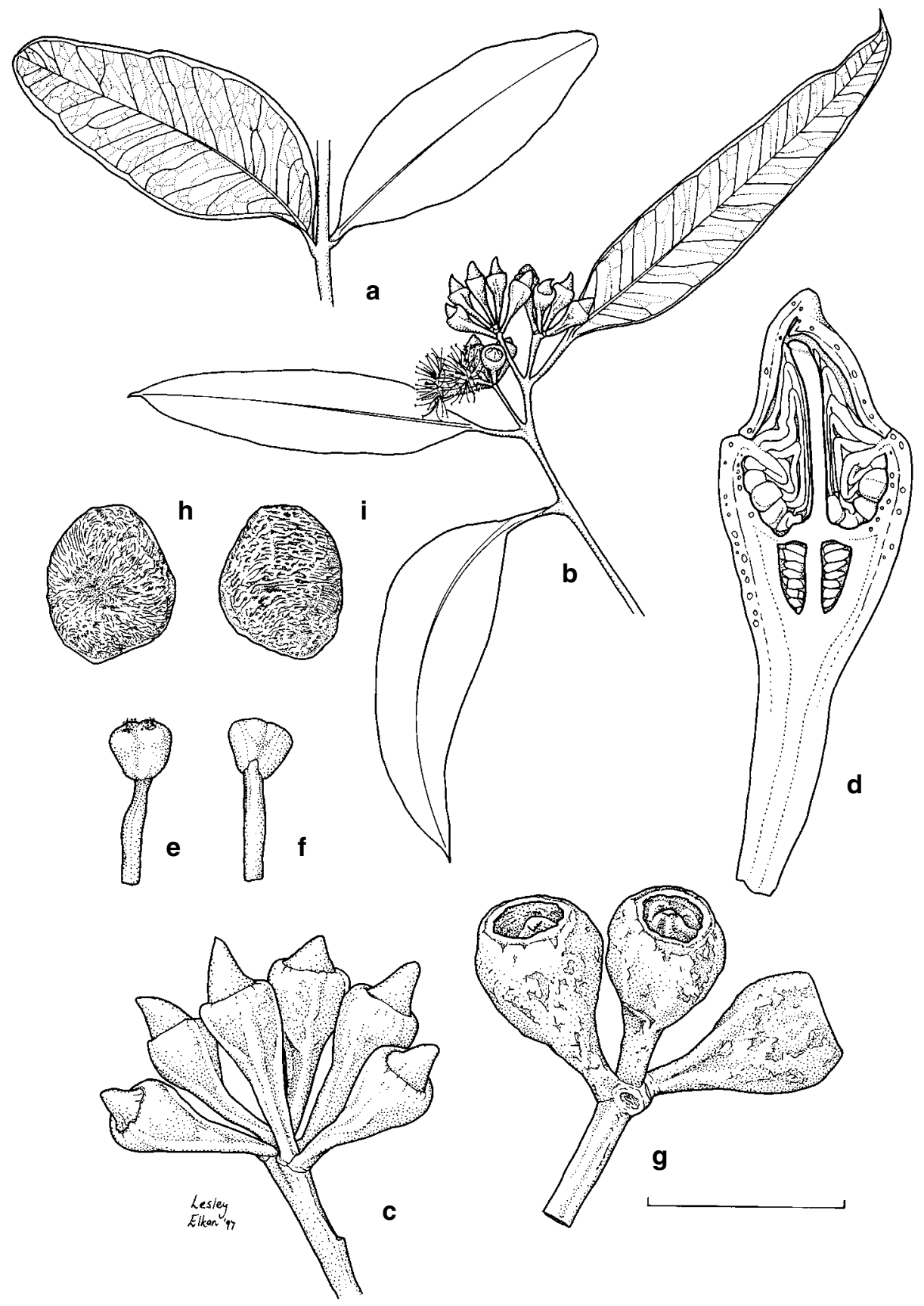

Fig. 5. E. scopulorum. a, juvenile leaves. $\mathbf{b}$, adult leaves and inflorescences. $\mathbf{c}$, inflorescence and buds. d, transverse section of bud. e, f, anther. $\mathbf{g}$, fruit. $\mathbf{h}$, $\mathbf{i}$, seed (a from Hill 4888, b-g from K.D. Hill 4887). Scale bar: $a, b=4 \mathrm{~cm}, c=4 \mathrm{~mm}, \mathrm{~d}, \mathrm{e}=1 \mathrm{~cm}, \mathrm{f}, \mathrm{g}=2 \mathrm{~mm}$. 


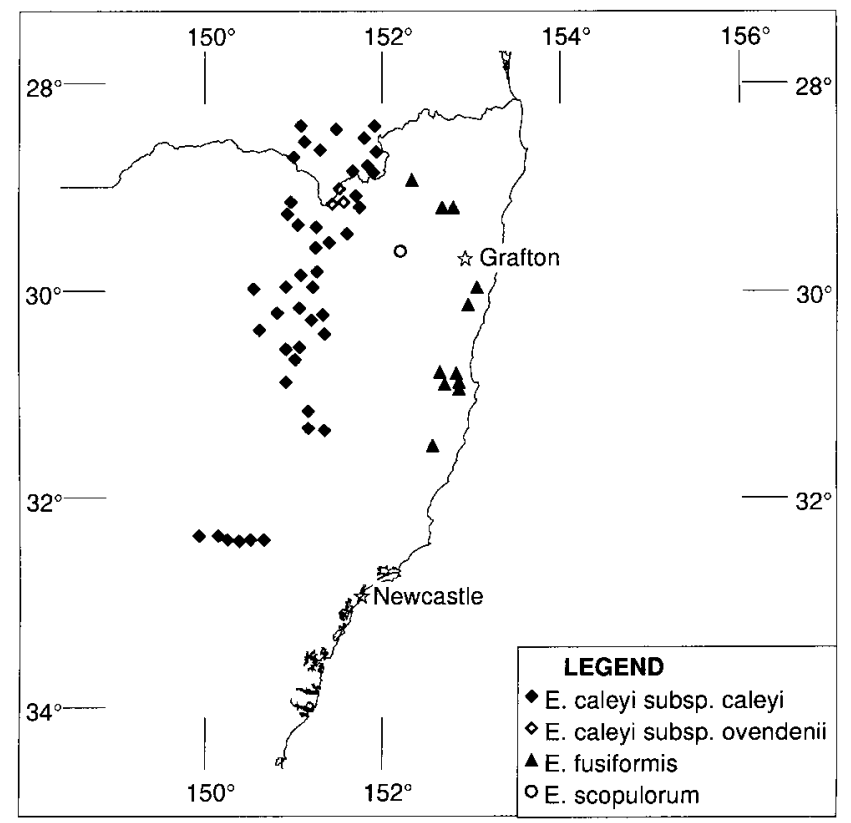

Fig. 6. Distribution of E. scopulorum, E. caleyi and E. fusiformis.

Conservation status: $2 \mathrm{RC}$.

The epithet is from the Latin scopulus, a cliff, from the occurrence on precipitous sites.

Specimens examined: New South Wales: Northern Tablelands: Peregrine Point, Gibraltar Range State Forest, Hill 4888 \& Richards, 28 Oct 1996 (NSW, BRI , CANB, K, MEL), Hill 4892 \& Richards, 28 Oct 1996 (NSW).

\section{Eucalyptus subcaerulea K.D. Hill, sp. nov.}

E. agglomeratae affinis sed foliis adultis juvenilibusque minoribus angustioribusque, alabastris minoribus, fructibus minoribus differt.

Type: New South Wales: Northern Tablelands: Cooraldooral trig., Gibraltar Range State Forest, K.D. Hill 4889 \& P.G. Richards, 28 Oct 1996 (holo NSW; iso AD, BRI, CANB, $\mathrm{HO}, \mathrm{K}, \mathrm{L}, \mathrm{MEL}, \mathrm{MO})$.

Tree to $15 \mathrm{~m}$ tall. Bark persistent, stringy, branches from ca. $2 \mathrm{~cm}$ diam. smooth, pale grey. Juvenile leaves mid-green, dull, hispid with simple hairs arising from raised oil glands, opposite on early nodes, becoming disjunct-opposite, broad-lanceolate to ovate, $3.0-6 \mathrm{~cm}$ long, $12-26 \mathrm{~mm}$ wide, petioles $1-4 \mathrm{~mm}$ long. Intermediate leaves broad-lanceolate, glabrous, $6-10 \mathrm{~cm}$ long, $1.7-3.0 \mathrm{~cm}$ wide. Adult leaves glossy green with a bluish sheen, glabrous, disjunct-opposite, similifacial, lanceolate, acute or apiculate, $4.5-11 \mathrm{~cm}$ long, $1.2-2.6 \mathrm{~cm}$ wide; petioles $0.9-1.5 \mathrm{~cm}$ long. Inflorescences axillary; umbellasters many-flowered (more than 11). Peduncles slightly flattened or angular, 5-10 mm long. Pedicels absent, or terete and to $1 \mathrm{~mm}$ long if present. Mature buds fusiform, 5-6 mm long, 1.5-2.5 mm diam. Calyptra conical, acute, about as long as or slightly longer than hypanthium. Stamens irregularly flexed, all fertile. Anthers versatile, dorsifixed, reniform, opening by confluent oblique slits. Fruits tightly clustered, globular, apically strongly constricted, 3-4-locular, 4-5 mm long, 5-7 mm diam. 


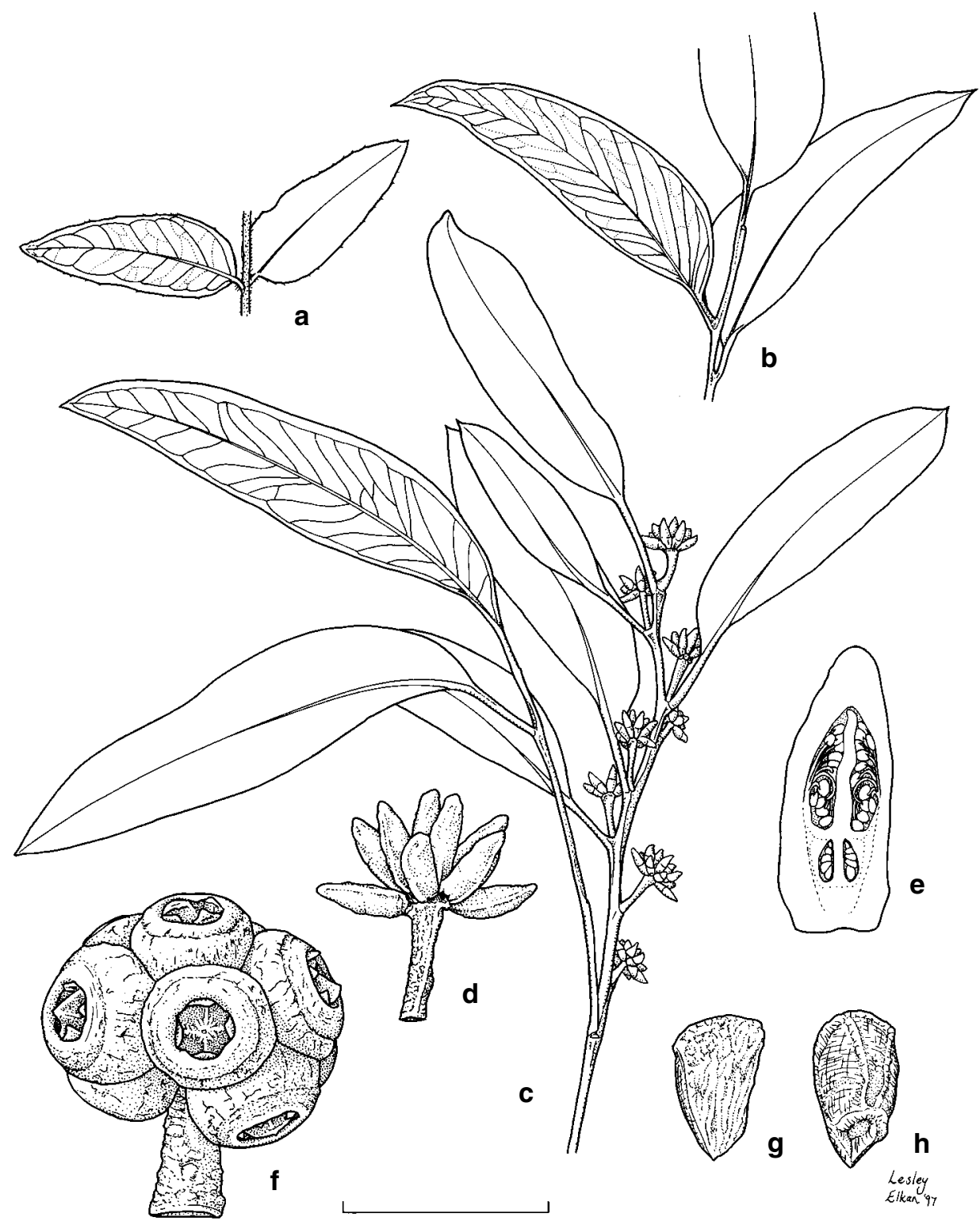

Fig. 7. E. subcaerulea. a, juvenile leaves. b, intermediate leaves. $\mathbf{c}$, adult leaves and inflorescences. d, inflorescence and buds. e, transverse section of bud. f, fruit. $g$, h, seed. (a,b from Hill 4890, b from Hill 4891, c-j from Hill 4889). Scale bar: a, b, c $=4 \mathrm{~cm}, \mathrm{~d}=4 \mathrm{~mm}, \mathrm{e}=2 \mathrm{~mm}, \mathrm{f}, \mathrm{g}=1 \mathrm{~cm}$. 
Table 4. Comparison of E. agglomerata and E. subcaerulea.

$\begin{array}{lll}\text { Juvenile leaves } & \begin{array}{l}\text { E. agglomerata } \\ \text { ovate }\end{array} & \begin{array}{l}\text { E. subcaerulea } \\ \text { broad-lanceolate } \\ \text { to ovate }\end{array} \\ \mathbf{c m} & 4-7 \times 2.0-4.5 & 3.0-6 \times 1.2-2.6 \\ \text { Petioles cm } & 0.5-1.0 & 0.1-0.4 \\ \text { Intermediate leaves } & \text { broad-lanceolate } & \text { broad-lanceolate } \\ \text { cm } & 8-15 \times 3.0-5.0 & 6-10 \times 1.7-3.0 \\ \text { Adult leaves } & \text { lanceolate } & \text { lanceolate } \\ \text { cm } & 10-14 \times 1.8-3.0 & 4.5-11 \times 1.2-2.6 \\ \text { Petioles cm } & 1.0-1.5 & 0.9-1.5 \\ \text { Peduncles mm } & 6-13 & 5-10 \\ \text { Pedicels mm } & 0 & 0-1 \\ \text { Buds mm } & 5-8 \times 2-3 & 5-6 \times 1.5-2.5 \\ \text { Fruits mm } & 5-7 \times 7-10 & 4-5 \times 5-7\end{array}$

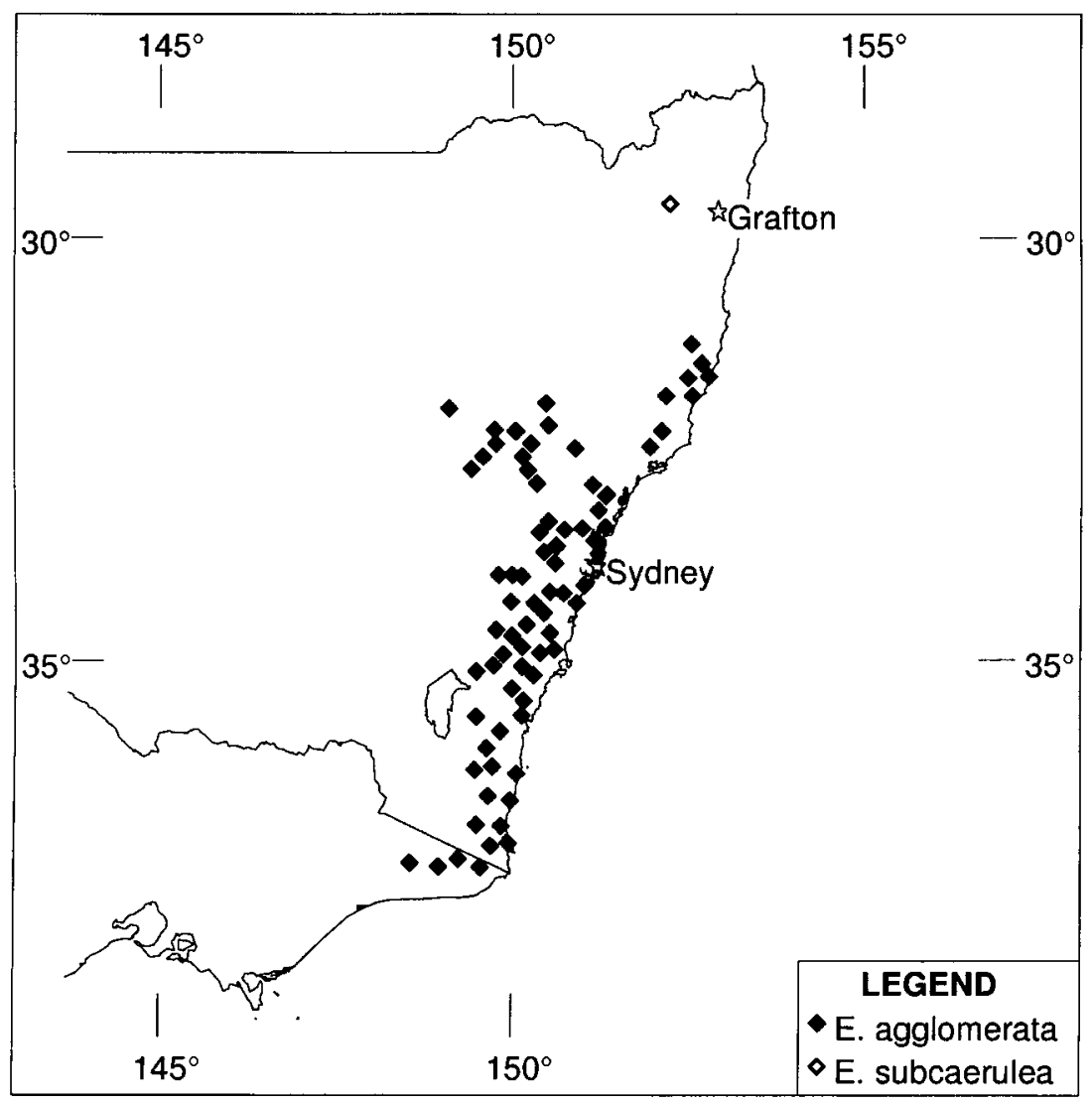

Fig. 8. Distribution of E. subcaerulea and E. agglomerata. 
Calyptra scar and stemonophore flat, c. 0.2-0.4 mm wide. Disc raised, glossy reddish brown, 1-1.5 mm wide. Valves broadly triangular, obtuse, slightly raised, tips level with disc. (Fig. 7).

Notes: E. subcaerulea is nearest to E. agglomerata Maiden, from which it is readily distinguished by the smaller, narrower adult and juvenile leaves with lower length:breadth ratios in both, and smaller buds and fruits (Table 4).

E. subcaerulea and E. agglomerata are placed in Section Renantherae of subgenus Monocalyptus (Pryor \& Johnson 1970) by the renantherous anthers. Within the section, they are placed in Series Capitellatae (the stringybarks) by the stringy bark and the hispid juvenile leaves. Both taxa are distinguished within that group by the broad juvenile leaves that become glabrous at an early stage, the closely clustered and more or less sessile fruits and the bluish sheen of the adult leaves.

Distribution: known only from a few small stands in the Gibraltar Range State Forest in the New England region of north-eastern New South Wales (Fig. 8).

Ecology: locally dominant in a band around the upper slopes of a steep ridge, on gritty sandy soils over granite and among outcropping boulders. E. campanulata R. Baker occurs in adjacent woodland, with some individuals among the E. subcaerulea population. The understorey is mainly grassy, dominated by Poa sp.

Conservation status: $2 \mathrm{RC}$.

The epithet is from the Latin caerulea, blue, and the Latin prefix sub-, somewhat, in reference to the blue sheen of the adult foliage that, while always present, is not always obvious.

Specimens examined: New South Wales: Northern Tablelands: Cooraldooral trig., Gibraltar Range State Forest, Hill 4890, 4891 \& Richards, 28 Oct 1996 (NSW, BRI, CANB).

\section{Acknowledgments}

Peter Richards is gratefully acknowledged for drawing attention to E. scopulorum and E. subcaerulea, and for valuable assistance in the field. Jeff Thomas drew attention to the new subspecies of E. pachycalyx. Peter Wilson is thanked for assistance with Latin diagnoses. Thanks are due to Leonie Stanberg for continued valuable assistance in the field and the herbarium, and Lesley Elkan for the illustrations.

\section{References}

Blakely, W.F. (1934) A Key to the Eucalypts (The Worker Trustees: Sydney).

Brooker, M.I.H. (1985) The ironbarks allied to Eucalyptus crebra F. Muell, and the description of a new species, E. quadricostata, in the group. Austrobaileya 2: 148-152.

Chippendale, G.M. (1988) Eucalyptus, Angophora. In George, A.S. (ed.), Flora of Australia, vol. 19 (Australian Government Publishing Service: Canberra).

Hill, K.D. (1991) Eucalyptus. Pp. 76-142 in Harden, G.J. (ed.), Flora of New South Wales, vol. 2 (New South Wales Press University: Kensington).

Pryor, L.D. \& L.A.S. Johnson (1971) A Classification of the Eucalypts (ANU Press: Canberra). 